October 2003 - NREL/CP-500-34662

\title{
Acoustic Tests of Small Wind Turbines
}

\section{Preprint}

P. Migliore, J. van Dam, and A. Huskey

To be presented at the 2004 Wind Energy Symposium Reno, Nevada January 5-8, 2004

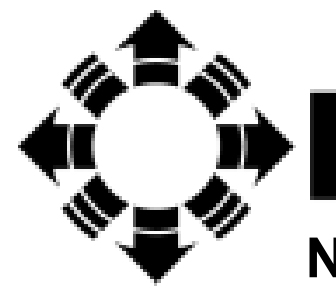

National Renewable Energy Laboratory

1617 Cole Boulevard

Golden, Colorado 80401-3393

NREL is a U.S. Department of Energy Laboratory

Operated by Midwest Research Institute $\bullet$ Battelle $\bullet$ Bechtel

Contract No. DE-AC36-99-G010337 


\section{NOTICE}

The submitted manuscript has been offered by an employee of the Midwest Research Institute (MRI), a contractor of the US Government under Contract No. DE-AC36-99G010337. Accordingly, the US Government and MRI retain a nonexclusive royalty-free license to publish or reproduce the published form of this contribution, or allow others to do so, for US Government purposes.

This report was prepared as an account of work sponsored by an agency of the United States government. Neither the United States government nor any agency thereof, nor any of their employees, makes any warranty, express or implied, or assumes any legal liability or responsibility for the accuracy, completeness, or usefulness of any information, apparatus, product, or process disclosed, or represents that its use would not infringe privately owned rights. Reference herein to any specific commercial product, process, or service by trade name, trademark, manufacturer, or otherwise does not necessarily constitute or imply its endorsement, recommendation, or favoring by the United States government or any agency thereof. The views and opinions of authors expressed herein do not necessarily state or reflect those of the United States government or any agency thereof.

Available electronically at http://www.osti.gov/bridge

Available for a processing fee to U.S. Department of Energy and its contractors, in paper, from:

U.S. Department of Energy

Office of Scientific and Technical Information

P.O. Box 62

Oak Ridge, TN 37831-0062

phone: 865.576.8401

fax: 865.576.5728

email: reports@adonis.osti.gov

Available for sale to the public, in paper, from:

U.S. Department of Commerce

National Technical Information Service

5285 Port Royal Road

Springfield, VA 22161

phone: 800.553 .6847

fax: 703.605.6900

email: orders@ntis.fedworld.gov

online ordering: http://www.ntis.gov/ordering.htm

Printed on paper containing at least $50 \%$ wastepaper, including $20 \%$ postconsumer waste 


\title{
ACOUSTIC TESTS OF SMALL WIND TURBINES ${ }^{*}$
}

\author{
P. Migliore, J. van Dam and A. Huskey \\ National Renewable Energy Laboratory, National Wind Technology Center \\ 1617 Cole Boulevard, Golden, Colorado 80401, USA \\ paul_migliore@nrel.gov; jeroen_van_dam@nrel.gov; arlinda_huskey@nrel.gov
}

\begin{abstract}
$\underline{\text { ABSTRACT }}$
Eight small wind turbines ranging from 400 watts to $100 \mathrm{~kW}$ in rated power were tested for acoustic emissions at the U.S. Department of Energy's National Renewable Energy Laboratory. Rigorous test procedures based on international standards were followed for measurements and data analyses. Results are presented in the form of sound pressure level versus wind speed, where the sound was recorded downwind of the turbine at a distance equal to the hub height plus half the rotor diameter. When there was sufficient separation between wind turbine noise and background noise, the apparent sound power level was calculated. In several cases, this was not possible. The implications of this problem are discussed briefly. Some of the configurations tested were specifically developed to reduce the noise level of their predecessors. Test data for these machines demonstrate marked progress toward quieter turbines.
\end{abstract}

\section{INTRODUCTION}

Until recently, wind turbine manufacturers and operators were challenged by the tasks of keeping machines operating reliably and improving energy capture. Although dramatic improvements have been made in both areas, there have been occasions when acoustic emissions proved so vexing they overshadowed performance and reliability issues. For example, some wind turbines suffer an unfavorable reputation for noise problems associated with high tip speeds, furling, or blade flutter. The U.S. Department of Energy (DOE) and its National Renewable Energy Laboratory (NREL) are engaged in several turbine research and demonstration projects focused on reducing the cost of energy at low wind speed sites. Recent analyses have shown that this effort, if successful, will lead to the installation of wind turbines in large numbers. In this circumstance, it is essential that the turbines available for deployment are quiet. This suggests there should be an effort by NREL

\footnotetext{
* This work was performed at the National Renewable Energy Laboratory in support of the U.S. Department of Energy under Contract No. DE-AC36-99GO10337.

${ }^{\S}$ This material is declared a work of the U.S. Government and is not subject to copyright protection in the United States.
}

to measure the acoustic signature of existing turbines and work diligently to reduce (below the state of the art) the signatures of new turbines being developed. Coincidentally, with recent energy shortages and the ensuing statewide deployment incentives, there is resurgent interest in small wind turbines for distributed generation. Because of the potential for installation near residences, noise may be even more important for small turbines than for large turbines installed in wind power plants.

Because small wind turbines are sold in large numbers and located close to people, there is a need for reliable noise data. If it was available, homeowners and local authorities could use the information to develop expectations regarding noise production before the turbines are actually installed. Furthermore, based on field test observations and the influence of the parameters investigated, improvements to the turbines might be made with relative ease and low cost.

As part of its aeroacoustic research program, NREL performed acoustic tests [1] on eight small wind turbines with power ratings from $400 \mathrm{~W}$ to $100 \mathrm{~kW}$. The goals of these tests were to develop a database of acoustic signatures to compare new and existing turbines and to establish targets for low-noise rotors. Test results will be documented and disseminated in the form of NREL reports, technical papers, seminars, and colloquia. This is part of broader effort to support the U.S. wind industry in applying rational acoustic-design principles to the development and deployment of advanced wind turbines.

Tests were conducted on two Bergey Excel and one XL.1 turbines, one Southwest Windpower Whisper $\boldsymbol{H} 4 \mathbf{O}$ and two AIR turbines, an Atlantic Orient Corporation $A O C$ 15/50, and a Northern Power Systems North Wind 100. In some cases, more than one configuration was tested to demonstrate noise reduction techniques. Measurements were made according to procedures described in the International Electrotechnical Commission (IEC) standard for acoustic noise measurement techniques [2] with minor modifications that were necessary for small turbines. In addition to the acoustic signals, wind speed and direction, turbine power and rotor speed were measured. In this paper, results are 
presented as sound pressure level and apparent sound power level for several wind speeds of interest. In the NREL report [1], noise spectra of sound pressure level versus imission ${ }^{1}$ frequency are also provided.

\section{MEASUREMENTS AND DATA ANALYSES}

Acoustic tests were conducted at the National Wind Technology Center (NWTC) near Boulder, Colorado. The site is located in somewhat complex terrain at an approximate elevation of $1850 \mathrm{~m}$ above sea level. The soil is covered with grassy vegetation and measurements indicate that the roughness length is approximately $0.05 \mathrm{~m}$. A gravel mine and concrete plant to the west are the main sources of background noise, although passing automobiles and airplanes also contribute. The prevailing wind direction is $292^{\circ}$ relative to true north.

Data were collected and analyzed according to the IEC standard [2] and NREL's quality assurance system [3] where possible. A reference microphone was located downwind of the turbine at a distance equal to the hub height plus half the rotor diameter. The microphone was placed on a circular plywood ground board that is one meter in diameter and $13 \mathrm{~mm}$ thick. The ground board was placed on a flat surface with no cavities beneath and the edges of the board were covered with dirt. Three additional microphones and ground boards were placed around some turbines for special tests. For this study, only data from the reference microphone were considered.

Wind speeds of $6-10 \mathrm{~m} / \mathrm{s}$ were measured, although measurements were taken outside this range for some turbines. Data were obtained for both the operating and parked conditions to allow correction for background noise. In circumstances of intrusive background noise, such as airplanes, automobiles or animals, the test data were discarded.

In addition to the acoustic pressures, wind speed and direction were measured. Both were essential to the subsequent analysis, and particular importance is assigned to having the reference microphone downwind of the turbine. For some tests, rotor speed and power were also measured with the expectation that these data might provide insight regarding noise-generating mechanisms.

\footnotetext{
${ }^{1}$ In the study of acoustics, the term "imission" refers to the noise level perceived by an observer at a receptor location. This is in contradistinction to the term "emission" which means 'something sent forth by emitting' and refers to the strength of the acoustic source.
}

Acoustic data were recorded on an 8-channel digital audiotape (DAT). All other data were recorded on a digital data logger. The analog microphone signals were recorded (digitally) on the DAT and then played back as analog inputs to a signal analyzer. Depending on the desired averaging period, either 1-minute or 10 -second average sound pressure ${ }^{2}$ levels were calculated. Although the IEC standard prescribes 1-minute averages, 10 -second averages seem to reflect the system dynamics better for small turbines. The sound pressure levels were synchronized with the averages of the other data channels, and the average wind speed was determined for each data point then normalized to standardized conditions.

The wind speed standardization equation takes the wind speed measured at any height and roughness length and normalizes it to a "standardized" height of $10 \mathrm{~m}$ and a roughness length of $0.05 \mathrm{~m}$. The formula used for this transformation is given in Equation (1).

$\mathrm{V}_{\mathrm{s}}=\mathrm{V}_{\mathrm{z}} \cdot\left[\ln (10 / 0.05) \ln \left(\mathrm{H} / \mathrm{z}_{0}\right) \div \ln (\mathrm{H} / 0.05) \ln \left(\mathrm{z} / \mathrm{z}_{0}\right)\right](1)$

where,

$\mathrm{V}_{\mathrm{s}} \quad$ is the standardized wind speed $(\mathrm{m} / \mathrm{s})$

$\mathrm{V}_{\mathrm{z}} \quad$ is the wind speed $(\mathrm{m} / \mathrm{s})$ measured at height $\mathrm{z}$

$\mathrm{H} \quad$ is the rotor center height (m)

$\mathrm{z}_{0} \quad$ is the roughness length of the test site (m)

$\mathrm{Z} \quad$ is the wind speed measurement height (m)

Noise measurements for the operating wind turbine (wind turbine plus background noise) are correlated with background-only noise measurements at standardized wind speeds. The noise measurements are then corrected for background noise using Equation (2).

$\mathrm{L}_{\mathrm{s}}=10 \cdot \log \left[10^{(\mathrm{Ls}+\mathrm{n} / 10)}-10^{(\mathrm{Ln} / 10)}\right]$

where,

\footnotetext{
${ }^{2}$ Sound is characterized by small pressure fluctuations overlaying atmospheric pressure, but the human ear does not respond linearly to the amplitude of sound pressure [4]. Doubling the amplitude produces the sensation of louder noise, but it seems far less than twice as loud. For this reason, the scale used to characterize sound pressure amplitudes is logarithmic, which is an approximation of the actual response of the human ear. The definition of sound pressure level $L_{p}$ is

$\mathrm{L}_{\mathrm{p}}=10 \cdot \log \left[\mathrm{p}^{2} \div \mathrm{p}_{\text {ref }}^{2}\right]$ expressed in decibels, $\mathrm{dB}$,

where $\mathrm{p}$ is the root mean square sound pressure and $\mathrm{p}_{\text {ref }}$ has a value of $2 \cdot 10^{-5} \mathrm{~Pa}$ corresponding to the weakest audible sound - the threshold of human hearing - at a frequency of $1000 \mathrm{~Hz}$.
} 
$\mathrm{L}_{\mathrm{s}} \quad$ is the equivalent sound pressure level $(\mathrm{dB})$ of the wind turbine operating alone

$\mathrm{L}_{\mathrm{s}+\mathrm{n}}$ is the equivalent sound pressure level (dB) of wind turbine plus background noise

$\mathrm{L}_{\mathrm{n}} \quad$ is the equivalent sound pressure level $(\mathrm{dB})$ of the background noise

The background-corrected sound pressure level of the wind turbine is translated into sound power ${ }^{3}$ level using Equation (3). The $6 \mathrm{~dB}$ constant accounts for the approximate doubling of sound pressure that occurs for microphone measurements on a ground board [2].

$\mathrm{L}_{\mathrm{WA}}=\mathrm{L}_{\text {Aeq, } \mathrm{c}}-6+10 \cdot \log \left[4 \pi \mathrm{R}_{1}^{2} / \mathrm{S}_{0}\right]$

where,

$\mathrm{L}_{\mathrm{WA}}$ is the background-corrected A-weighted ${ }^{4}$ apparent sound power level of the turbine, $\mathrm{dB}(\mathrm{A})$

$\mathrm{L}_{\text {Aeq, c }}$ is the background-corrected A-weighted sound pressure level determined from analysis of multiple data pairs as described below, $\mathrm{dB}(\mathrm{A})$

$\mathrm{R}_{1} \quad$ is the slant distance, in meters, between the microphone and the rotor center

$\mathrm{S}_{\mathrm{o}} \quad$ is the reference area, $\mathrm{S}_{\mathrm{o}}=1 \mathrm{~m}^{2}$

In practice, Equation (2) is not applied to individual data points. Instead, a large amount of data is accumulated and calculations are based on trends or averages. A linear regression is used to fit a straight line through the measured sound pressure level data for the operating wind turbine between the standardized wind speeds of 6 and $10 \mathrm{~m} / \mathrm{s}$. The process is repeated for back-

${ }^{3}$ Whereas sound pressure level is a property of the observer
location [4], the total strength of a source of sound is charac-
terized by the sound power emitted by the source. In general,
the sound power $\boldsymbol{P}$ transmitted through a surface $\boldsymbol{S}$ is the inte-
gral of the sound intensity $\boldsymbol{I}$ (energy transmitted per unit time
and unit area) over the surface. If the surface $\boldsymbol{S}$ encloses the
source of the sound, then $\boldsymbol{P}$ is the total sound power emitted
by the source. The definition of sound power level is

$\mathrm{L}_{\mathrm{w}}=10 \cdot \log \left[\boldsymbol{P} \div \boldsymbol{P}_{\text {ref }}\right]$ expressed in decibels, $\mathrm{dB}$,

where $\boldsymbol{P}_{\text {ref }}=10^{-12}$ watts is the standard reference sound power. The eardrum can detect incoming sound power as weak as one picowatt, and exposure to incoming sound power of more than one watt will result in some hearing loss.

${ }^{4}$ The ear is not equally sensitive to tones of different frequencies. Maximum response occurs between 3000 and $4000 \mathrm{~Hz}$, where the hearing threshold is somewhat less than $0 \mathrm{~dB}$. A $100 \mathrm{~Hz}$ tone, however, must have an intensity of $40 \mathrm{~dB}$ to be heard [4]. Therefore, weighted sound levels have been introduced where lower frequencies are de-emphasized in a manner similar to human hearing. A-weighting is most commonly used and is well suited for sound levels that are not too high. ground noise measurements. Then, the backgroundcorrected sound pressure level is determined for a particular wind speed by subtracting the two results using Equation (2). However, according to the IEC Standard [2], if the difference in sound pressure level between the operating wind turbine and the background noise is less than $6 \mathrm{~dB}$, the data may not be used for determination of the sound power level at that wind speed. If the difference is at least $6 \mathrm{~dB}$, the sound power level for the turbine is calculated from Equation (3).

A second method for calculating sound power level was used in some cases. All of the acoustic data for the operating turbine and for the background noise were sorted and energy averaged in $1-\mathrm{m} / \mathrm{s}$ wind speed bins centered on integer values. A sound pressure level for the operating turbine was calculated for each wind speed if there were more than three data points in the bin. This process was repeated for background measurements. For each wind speed bin, the operating turbine noise was corrected for background noise using Equation (2). If the difference between the two was at least $6 \mathrm{~dB}$, the sound power level for the wind turbine operating alone was calculated using Equation (3). This method was used for the comparisons in Table 1.

In addition to evaluating the sound power level as described above, it is useful to examine the spectra of sound pressure level versus frequency. NREL uses one of two approaches, depending upon the availability of data. Either two 1-minute spectra or twelve 10-second spectra having wind speeds closest to the reporting wind speed were energy averaged to obtain one spectrum. These narrow band spectra, so called because small incremental frequency bands were used, were reported [1] for wind speeds of 6,8 , and $10 \mathrm{~m} / \mathrm{s}$.

In some cases, the narrow band spectra were analyzed for the presences of pure tones. That information is not reported here but may be found in the individual test reports $[5,6,7,8]$. The spectra were visually checked for the presence of possible tones. Similar spectra were developed for background noise around the same wind speeds to make sure that the peaks did not originate from the background noise. If there were no obvious tones indicated and nothing was heard during the tests, no further analysis was performed. If tones were observed, the Measnet [9] procedure was used to determine tonality. In this procedure, the critical band is identified and the tone and masking noise levels are calculated. The tonality value is the difference between the tone level and the masking noise level. 


\section{BERGEY EXCEL-S TURBINES}

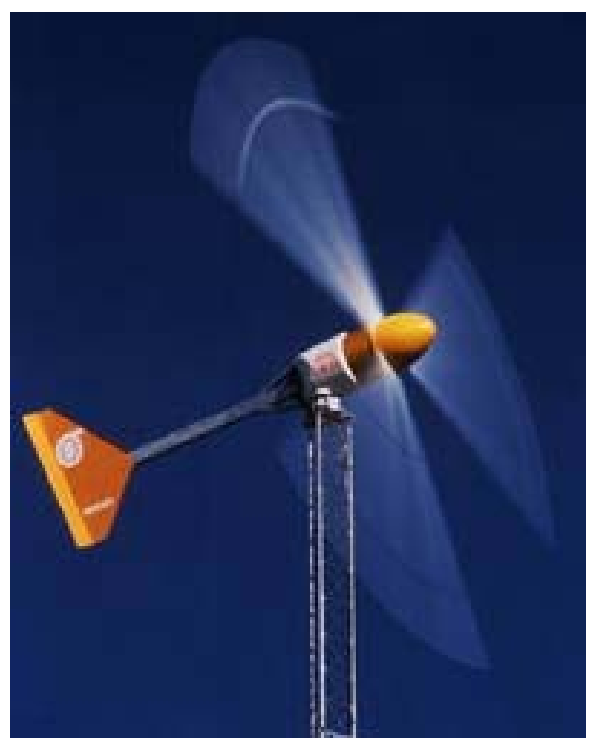

Bergey Windpower Company of Norman, Oklahoma, (www.bergey.com) manufactures the Excel-S (shown above), which is a three-blade upwind turbine that Bergey rates at $10 \mathrm{~kW}$ at a wind speed of $13 \mathrm{~m} / \mathrm{s}$. It is connected to a Bergey Gridtek inverter that provides power to the NWTC electrical grid. The Excel uses a permanent magnet alternator to produce three-phase variable frequency output at a nominal 240 -volts. The threephase output is rectified to DC power and then converted to single-phase 240 -volt $60 \mathrm{~Hz}$ AC power in the inverter. The turbine blades are constructed of pultruded fiberglass. In high wind speeds-greater than about $16 \mathrm{~m} / \mathrm{s}$ - the turbine will furl out of the wind to protect it from over-speeding.

The rotor diameter of the machine tested at the NWTC was $7 \mathrm{~m}$ and its hub height was $36.5 \mathrm{~m}$. The slant distance of the microphone, an important parameter in Equation (3), was $54.5 \mathrm{~m}$. To better reflect the dynamics of the turbine, 10-second averages were used instead of 1-minute averages. Wind speed was measured at hub height and standardized using Equation (1).

The Bergey Excel operates both loaded and unloaded, a condition defined by whether or not it is connected to the load. The load in this case was the utility grid. Because the operating condition has a strong influence on the noise characteristics, measurements were taken under both conditions.

Figure 1 shows the measured sound pressure levels for an earlier version of the $\boldsymbol{E x c e l}$ with BW03 airfoils. The graph also shows sound pressure levels measured when the inverter was offline (turbine was unloaded) for all or part of the 10-second averaging period. In this situa- tion, the noise level increases approximately $4 \mathrm{~dB}(\mathrm{~A})$ to $5 \mathrm{~dB}(\mathrm{~A})$ compared to the turbine loaded. The apparent sound power level at $8 \mathrm{~m} / \mathrm{s}$, a common comparison point for wind turbines, was found to be $98.4 \mathrm{~dB}(\mathrm{~A})$.

The Excel was also tested with a second blade set that had a reduced rotor diameter of $6.17 \mathrm{~m}$, an opposite direction of rotation, and a Selig-Hanley SH3052 airfoil. The slant distance from the turbine to the microphone was the same as for the previous BW03 tests. Figure 2 shows a dramatic reduction in measured noise for this configuration. For example, in the range of $8-$ $14 \mathrm{~m} / \mathrm{s}$ the sound pressure level of the operating turbine was reduced by approximately $10-15 \mathrm{~dB}(\mathrm{~A})$.

Although the turbine noise could not be separated from the background noise for the SH3052 blades (Figure 2), the sound pressure level can be compared directly to the BW03 blades (Figure 1), because the slant distance was identical in both tests, and the background noise levels were virtually the same. In high wind conditions, both configurations became noisy when the inverter was offline and the unloaded rotor increased speed. Thus, it is desirable to prevent the inverter from going offline under normal operating conditions, a feature that was not characteristic of the turbine tested at the NWTC.

\section{SOUTHWEST WINDPOWER AIR TURBINES}

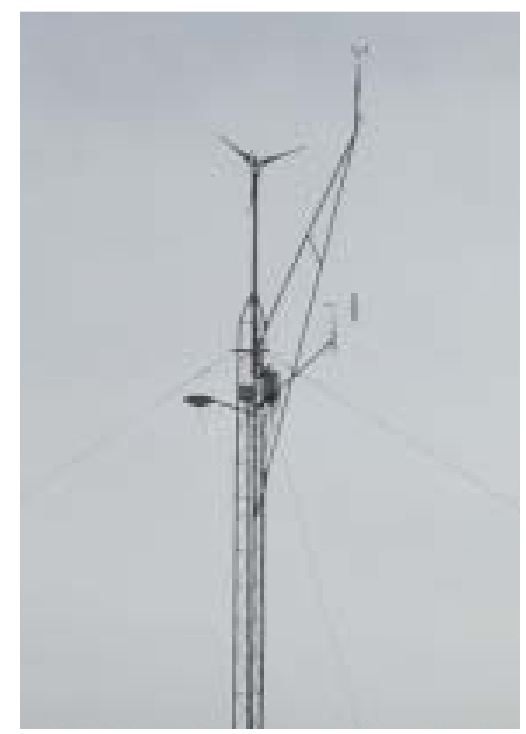

Southwest Windpower, Inc., of Flagstaff, Arizona, (www.windenergy.com) produces the AIR 403 (shown above), a three-blade upwind turbine with a manufacturer's rated power of 400 watts at $12.5 \mathrm{~m} / \mathrm{s}$. The DC output of the turbine was connected to a DC bus that was also connected to a battery bank and an Enermaxer. This device maintained the DC bus voltage at a constant 13.2 volts to prevent the turbine from shutting 
down when the batteries were fully charged. The $\boldsymbol{A I R}$ 403 is a free yaw turbine that employs aero-elastic stall, also known as flutter, for over-speed protection.

The machine tested at the NWTC had a rotor diameter of $1.14 \mathrm{~m}$ and a hub height of $13.3 \mathrm{~m}$. The anemometer was mounted on a boom from the same tower. The microphone at the reference position was located at a slant distance of $19.1 \mathrm{~m}$.

Figure 3 shows the measured sound pressure level for the AIR 403. Three patterns are distinguishable. At higher wind speeds, the turbine flutters as a means of over-speed control. Green triangle markers indicate the 10 -second time periods during which the blades experienced flutter. Small horizontal bars on the markers indicate continuous flutter. The 10 -second time periods during which the blades did not flutter are indicated with blue diamond markers. It appears that flutter increases the noise of the turbine approximately $10-12$ $\mathrm{dB}(\mathrm{A})$. The apparent sound power level at $8 \mathrm{~m} / \mathrm{s}$, when the blades do not flutter, was found to be $81.2 \mathrm{~dB}(\mathrm{~A})$.

We were not able to collect background noise data at higher wind speeds nor calculate the sound power level when the blades flutter. However, we estimated a background noise level of $65 \mathrm{~dB}(\mathrm{~A})$ by extrapolating the available data to $20 \mathrm{~m} / \mathrm{s}$. By binning data between 18 and $20 \mathrm{~m} / \mathrm{s}$, we estimated a sound power level of 112.5 $\mathrm{dB}(\mathrm{A})$ for the blades in flutter, which is quite loud.

To mitigate the impact of this blade flutter, Southwest Windpower developed a new version of the turbine called Air X. The Air $\boldsymbol{X}$ controller causes the blades to stall if the rotor speed or DC voltage exceed set limits. A marine version of this turbine was tested at the NWTC. The distinctions from the standard version are corrosion protection and sealed electronics.

The measured sound pressure level of the $\boldsymbol{A I R} \boldsymbol{X}$ is shown in Figure 4. During normal operation, when the blades are not fluttering, two groups of data can be distinguished. One group, which is representative of power production mode, is plotted above the background noise level. A second group overlays the background noise level, shown in this plot with open symbols. This lower noise level-sometimes as much as 10 $\mathrm{dB}(\mathrm{A})$ lower-occurs when the turbine is operating in stall mode or automatic shutdown mode. This is caused by the turbine controller attempting to limit the rotor speed. In turbulent winds, which are typical of the NWTC test site, rotor speed control is not precise. Therefore, the 10 -second averages do not always reflect the same rotor speed.
If a curve is fit or a bin analysis is performed using the entire set of normal operation data, the resulting sound pressures will be mix of normal operation, stall mode, and parked data. This procedure would underestimate the noise level an observer would experience during the normal power production mode.

Figure 4 exhibits a curious trend between 6 and $10 \mathrm{~m} / \mathrm{s}$, where the sound pressure level is unexpectedly low. Repeated reviews of the test data failed to provide an explanation for this behavior, although it is likely to be a result of the controller limiting rotor speeds.

In comparing Figures 3 and 4, it is evident that the control strategy implemented on the $\boldsymbol{A I R} \boldsymbol{X}$ was successful in reducing the occurrence of flutter-induced noise.

\section{BERGEY XL.1 TURBINE}

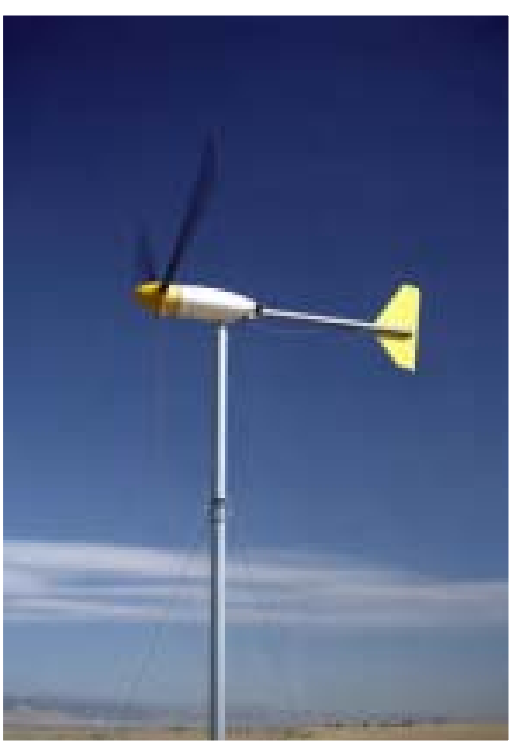

The Bergey XL.1 (shown above) is a three-blade upwind turbine with a manufacturer's rated power of 1 $\mathrm{kW}$ at a wind speed of $11 \mathrm{~m} / \mathrm{s}$. A permanent magnet generator produces three-phase variable frequency output that is rectified to 24 volts DC. The turbine uses sideways furling for over-speed protection. It has a rotor diameter of $2.5 \mathrm{~m}$ and a hub height of $9 \mathrm{~m}$. The microphone at the reference position was located at a slant distance of $13.8 \mathrm{~m}$.

Figure 5 shows the measured sound pressure level for the $\boldsymbol{X L} .1$. The measured values are quite low and the apparent sound power level at $8 \mathrm{~m} / \mathrm{s}$ cannot be reported because the turbine noise level could not be separated from the background noise. 


\section{SOUTHWEST WINDPOWER WHISPER H40}

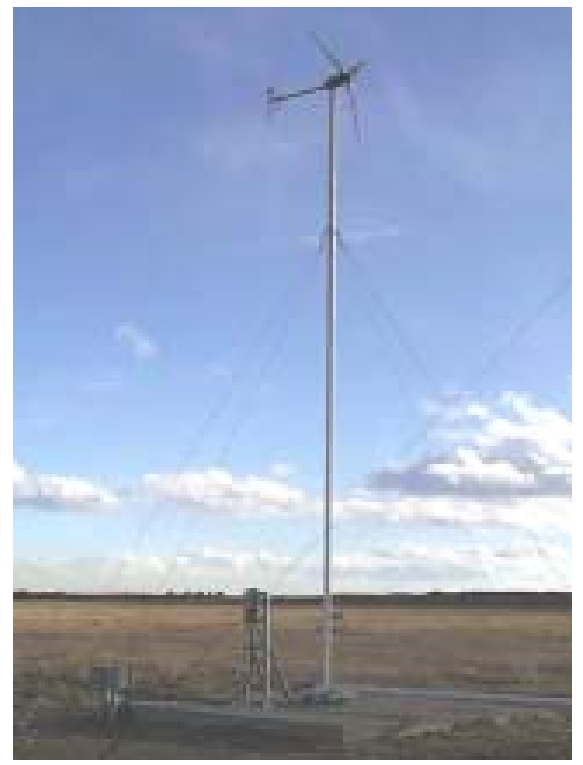

The Whisper H40 (pictured above) is a three-blade upwind turbine with a rated power of 900 watts at a wind speed of $12.5 \mathrm{~m} / \mathrm{s}$. As tested, the turbine had its 24-volt DC output grid connected via a Trace SW4024 inverter. Power and over-speed control are by a patented "angle governor" that combines horizontal and vertical furling.

The Whisper's rotor diameter was $2.1 \mathrm{~m}$ and hub height was $9.1 \mathrm{~m}$. The microphone at the reference position was located at a slant distance of $13.6 \mathrm{~m}$. Test data were averaged over 10-second periods instead of 1 minute periods to better characterize the noise at higher wind speeds when the turbine employs over-speed control. Wind speed measurements, which were obtained from a hub-height anemometer located on a compass heading of $292^{\circ}$ from the turbine, were standardized to the reference height of $10 \mathrm{~m}$.

Figure 6 shows the measured sound pressure level for the Whisper H40. There was sufficient separation between the turbine and background noise to determine the apparent sound power level at $8 \mathrm{~m} / \mathrm{s}$. It was found to be $84.9 \mathrm{~dB}(\mathrm{~A})$

\section{ATLANTIC ORIENT CORPORATION AOC 15/50 TURBINE}

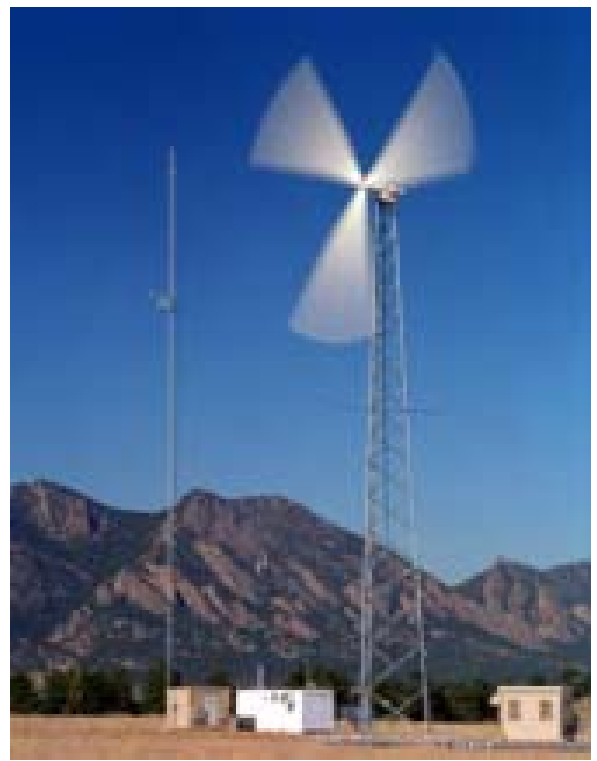

The Atlantic Orient Corporation, of Norwich, Vermont, and Charlottetown, Prince Edward Island, Canada, (www.aocwind.net) manufactures the $A O C$ 15/50 wind turbine (pictured above). It is a three-blade, downwind, free yaw machine with a rated power of $50 \mathrm{~kW}$ at 12 $\mathrm{m} / \mathrm{s}$. Its fixed-pitch, constant speed, stall-regulated, 15$\mathrm{m}$ diameter rotor employs 7.2-m wood-epoxy blades manufactured by Aerpac/Merrifield Roberts. The rotor is mounted on the gearbox low-speed shaft, and the three-phase induction generator is connected to the gearbox high-speed shaft. The tower is a 24.4- $\mathrm{m}$ high, freestanding, three-leg lattice steel structure that provides a hub height of $25 \mathrm{~m}$.

The turbine employs three independent brake systems. Electro-magnetically controlled tip plates are installed on the blade tips to provide aerodynamic braking. A capacitor/resistor network provides dynamic braking, and a mechanical brake is used for parking the rotor.

Figure 7 shows the measured 1-minute average sound pressure levels as a function standardized wind speed. The slant distance of the microphone was 41.2 meters. The apparent sound power level at $8 \mathrm{~m} / \mathrm{s}$ was found to be $101.1 \mathrm{~dB}(\mathrm{~A})$ [6]. 


\section{NORTHERN POWER SYSTEMS NORTH WIND 100 TURBINE}

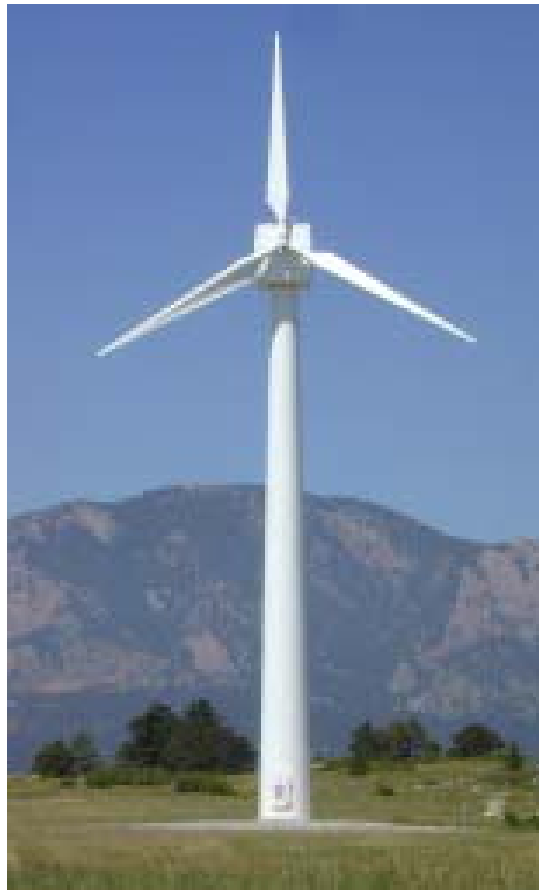

Northern Power Systems of Waitsfield, Vermont, (www.northernpower.com) manufactures the North Wind 100 (shown above), a three-blade upwind turbine with a rated power of $100 \mathrm{~kW}$ at $13 \mathrm{~m} / \mathrm{s}$. Its fixed pitch, variable speed, stall controlled, 19.1-m diameter rotor employs modified ERS 0100 blades manufactured by TPI Composites. The test turbine was mounted on a 23.4-m tubular steel tower that provides a hub height of $25.0 \mathrm{~m}$. The grid-connected turbine uses a direct-drive (no gearbox) salient pole synchronous generator and is specially designed to operate in very cold climates.

Figure 8 shows the measured 1-minute average sound pressure level for the North Wind 100. The slant distance of the microphone was 42.0 meter. There was no difficulty obtaining the $6 \mathrm{~dB}$ separation between turbine and background noise [8], and the apparent sound power level at $8 \mathrm{~m} / \mathrm{s}$ was found to be $93.8 \mathrm{~dB}(\mathrm{~A})$.

Aeroacoustic emissions are a strong function of size. With a diameter of $19.1 \mathrm{~m}$, the North Wind 100 is larger than others in the test group. Comparisons [10] to similar turbines indicate that its sound pressure level is typical for machines of its size.

\section{COMPARISON OF TESTED TURBINES}

We wish to compare the acoustic signatures of all the turbines on a common basis, but owing to the difficulty of separating wind turbine noise from background noise for the quieter machines, a complete database is not available for all the turbines tested. For example, as noted above, it was not possible to calculate an apparent sound power level for the Bergey $\boldsymbol{X L}$.1. Still, important observations may be made from the data that are available. Table 1 and Figure 9 provide this information.

The $A O C$ 15/50 and the early version of the Excel with BW03 blades have the highest noise levels of the turbines tested. Because it was one of the largest turbines tested, we expected the $\boldsymbol{A O C} \mathbf{1 5 / 5 0}$ to be somewhat noisier. Test engineers also observed that mechanical noise was more prevalent than on other turbines. Furthermore, the $A O C \mathbf{O} \mathbf{1 5} / \mathbf{5 0}$ employs tip plates that are likely to add aeroacoustic noise. In support of this hypothesis, we note that tests of an $\boldsymbol{A W T - 2 6}$ turbine at the NWTC measured an increment of almost $2 \mathrm{~dB}(\mathrm{~A})$ for similar tip plates. These tests were conducted with a tip plate on one blade and conventional tip on the other, thus leaving no question of differences in test conditions or instrumentation.

Significantly, improvements made to the Excel reduced acoustic emissions to the point that turbine noise could not be separated from background noise. For this reason, the Excel with SH3052 airfoils does not appear in Figure 9, but Figures 1 and 2 corroborate this assertion.

The Air 403 data do not exhibit the smooth trends of the other turbines. By listening to the sound recordings, we learned that several of the measurements actually captured the noise of the blades in flutter. Figure 3, which was discussed previously, clearly illustrates this.

Considering the difficulties introduced by variations in background noise, it is interesting to compare the levels from different tests. Several of these are shown in Figure 10 , where it can be seen that a range of $10 \mathrm{~dB}(\mathrm{~A})$ is typical for most wind speeds. It appears that the variation in background noise is greater at low wind speeds than at high wind speeds where the noise of the wind itself masks some of the other constituents of background noise. We also observed that at low wind speeds, the highest background noise levels correspond to the test sites closest to the concrete plant. This was expected because of the relationship between sound pressure level and the distance from the source, as seen in Equation (3). Recognizing the importance of a quiet site for acoustic testing, we are exploring other locations at the NWTC (further from known noise sources) for future tests. 


\section{SUMMARY}

A series of field tests were conducted to measure the acoustic noise of several small wind turbines. Rigorous procedures for both testing and data analyses were followed. Because the NWTC is a turbulent site, the wind turbines, some of which have temperamental controls, sometimes have different acoustic signatures on different days even at the same wind speed. Particularly vexing is the variation in background noise and the inability to separate it from turbine noise for the quieter machines. This has prompted NREL researchers to seek quieter sites that are less susceptible to background noise variations.

In considering individual turbines, we conclude that for the Bergey Excel and Southwest Windpower AIR turbines, the manufacturers' efforts to reduce noise through the use of new airfoils or control techniques have resulted in quieter turbines.

In normal operation, the Excel turbine with SH3052 blades exhibits significantly lower noise than its predecessor with BW03 blades. NREL researchers attribute this improvement to the new airfoils and reduced tip speed owing to smaller rotor diameter. In high wind conditions and unloaded (inverter offline), both turbines become much noisier.

In normal power-production mode, the $\boldsymbol{A I R} 403$ and the AIR $\boldsymbol{X}$ exhibit similar noise characteristics. In high wind conditions, when the blades flutter, the AIR 403 becomes much noisier than in normal operation. Control improvements in the $\boldsymbol{A I R} \boldsymbol{X}$, which stall the blades when rotor speed exceeds set limits, reduced the occurrence of this flutter-induced noise.

For the Excel with SH 3052 blades, the $\boldsymbol{X L}$.1, and the Whisper $H 40$ at virtually all wind speeds above $7 \mathrm{~m} / \mathrm{s}$, separation between operating turbine and background noise levels was less than $6 \mathrm{~dB}(\mathrm{~A})$.

\section{ACKNOWLEDGEMENTS}

Conducting multiple test campaigns over many years while maintaining scientific rigor is a formidable challenge. Arlinda Huskey and Jeroen van Dam spent countless hours calibrating instruments; setting up experiments, some in miserable weather; listening to recordings; analyzing and plotting data; and writing reports. It is difficult to overstate their accomplishments as documented in this paper and the NREL report [1].

\section{REFERENCES}

[1] Migliore, P., van Dam, J. and Huskey, A., (2003). Acoustic Tests of Small Wind Turbines, NREL SR500-34601. Golden, CO: National Renewable Energy Laboratory

[2] International Electrotechnical Commission, First Edition, (1998). International Standard IEC 6140011, "Wind Turbine Generator Systems - Part 11: Acoustic Noise Measurement Techniques".

[3] NREL National Wind Technology Center, (2001). "Test Manual for the Acoustics Testing of Wind Turbines per ISO Guide 25, 1990".

[4] Wagner, S., Bareiß, R. and Guidati, G, (1996). "Wind Turbine Noise," Springer-Verlag, Berlin, pp. 14-21.

[5] Huskey, A. and Meadors, M., (2001). Wind Turbine Generator System, Acoustic Noise Test Report for the Whisper H40 Wind Turbine.

[6] Huskey, A. and van Dam, J., (2003), Wind Turbine Generator System, Acoustic Noise Test Report Revision 1 for the AOC 15/50 Wind Turbine, NREL Test Report.

[7] Huskey, A. and Meadors, M., (2003). Wind Turbine Generator System, Acoustic Noise Test Report for the Bergey Excel Wind Turbine, NREL Test Report.

[8] Huskey, A. and Meadors, M., (2002). Wind Turbine Generator System, Acoustic Noise Test Report for the NW100 Wind Turbine, NREL Test Report.

[9] "Measnet Acoustic Noise Measurement Procedure", (1997). www.measnet.org

[10] van Dam, J., (1999). "Trend in de akoestische bronsterktes van windturbines" (Trend in the acoustic sound power level of wind turbines), Energieonderzoek Centrum Nederland (Energy Research Center of the Netherlands ECN), Proceedings of the Netherlands Renewable Energy Conference. 


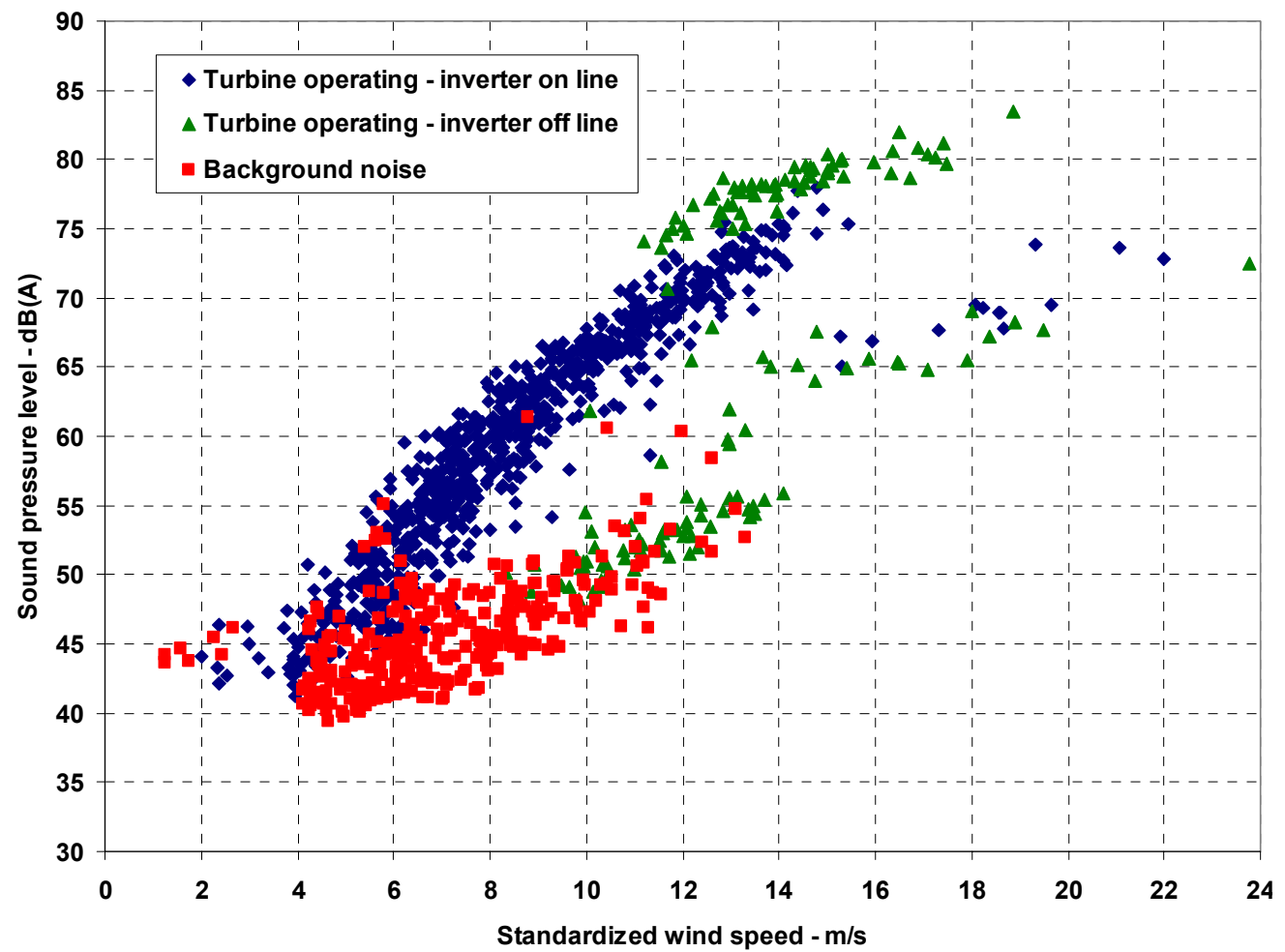

Figure 1. 10-second average sound pressure level for Bergey Excel-S with BW03 airfoils

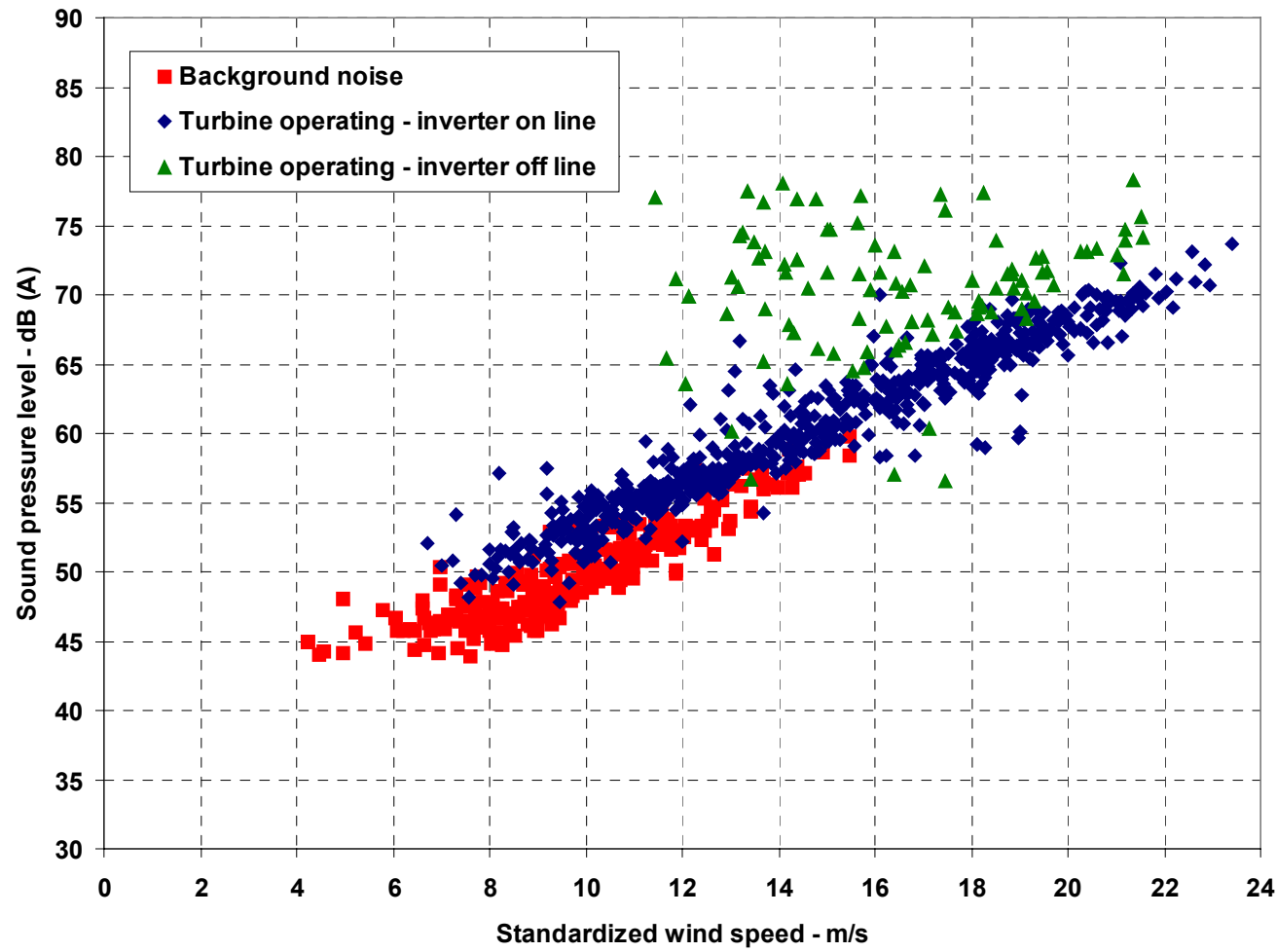

Figure 2. 10-second average sound pressure level for Bergey Excel-S with SH3052 airfoils 


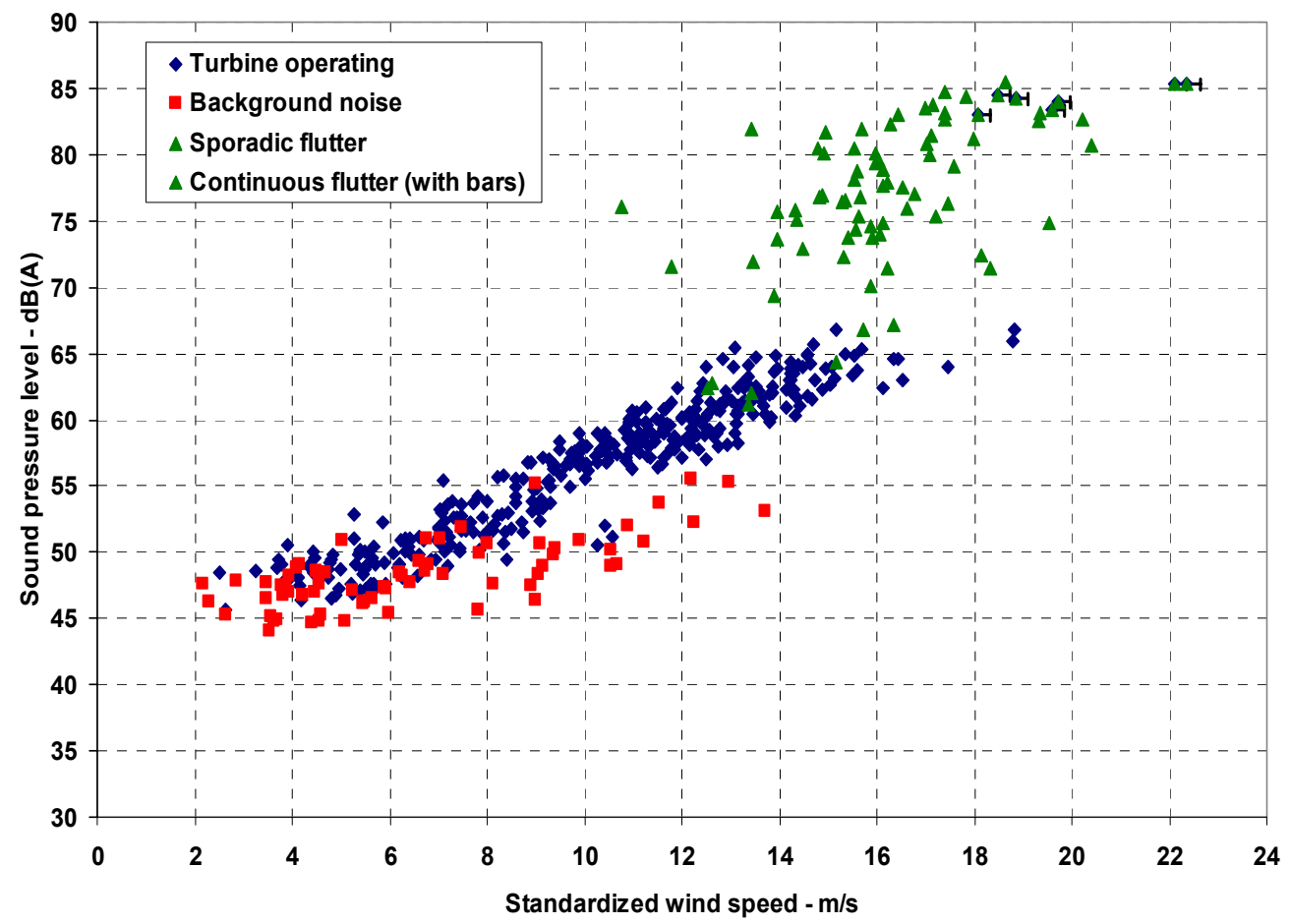

Figure 3. 10-second-average sound pressure level for Southwest Windpower AIR 403

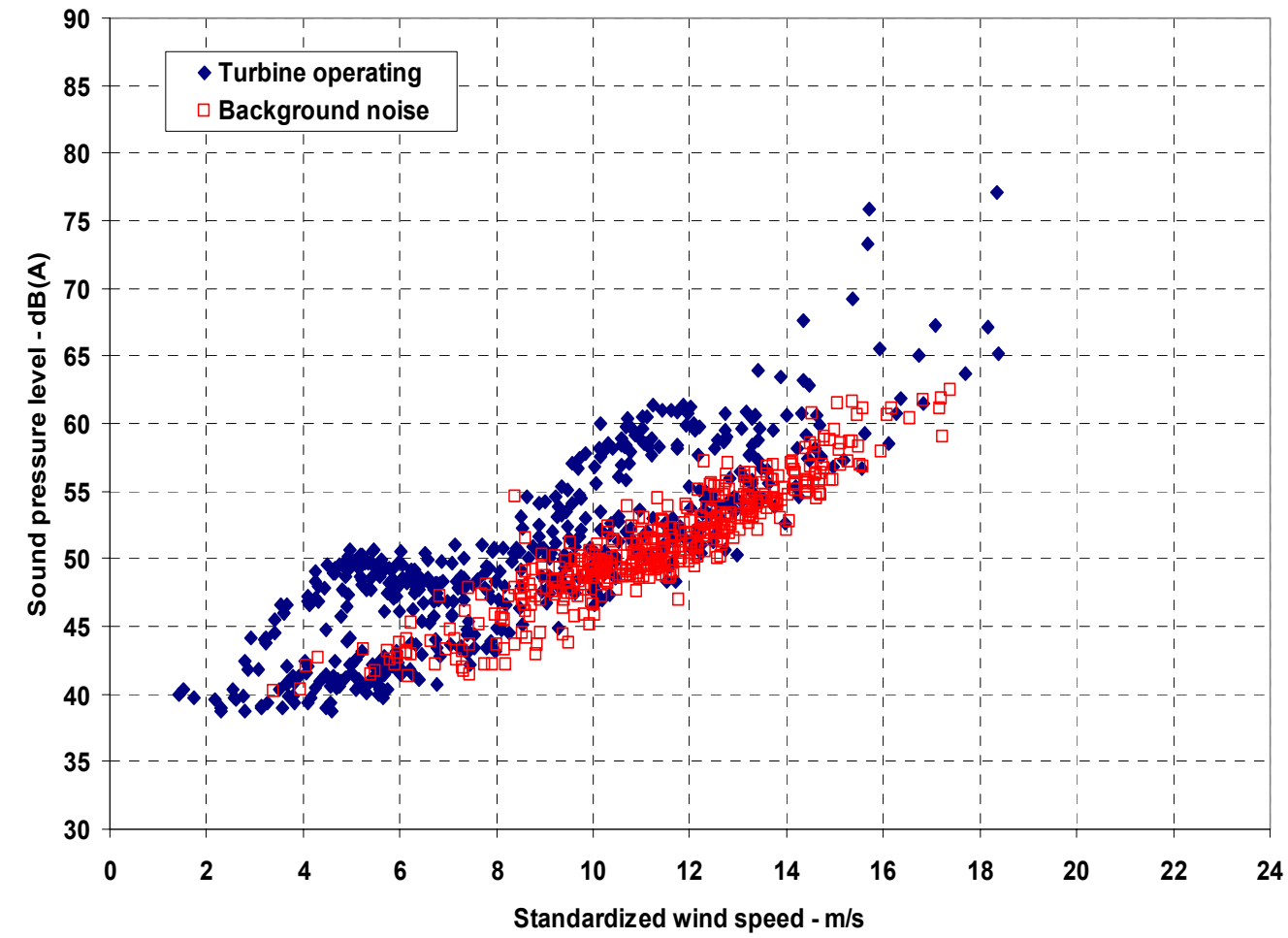

Figure 4. 10-second average sound pressure level for Southwest Windpower AIR X 


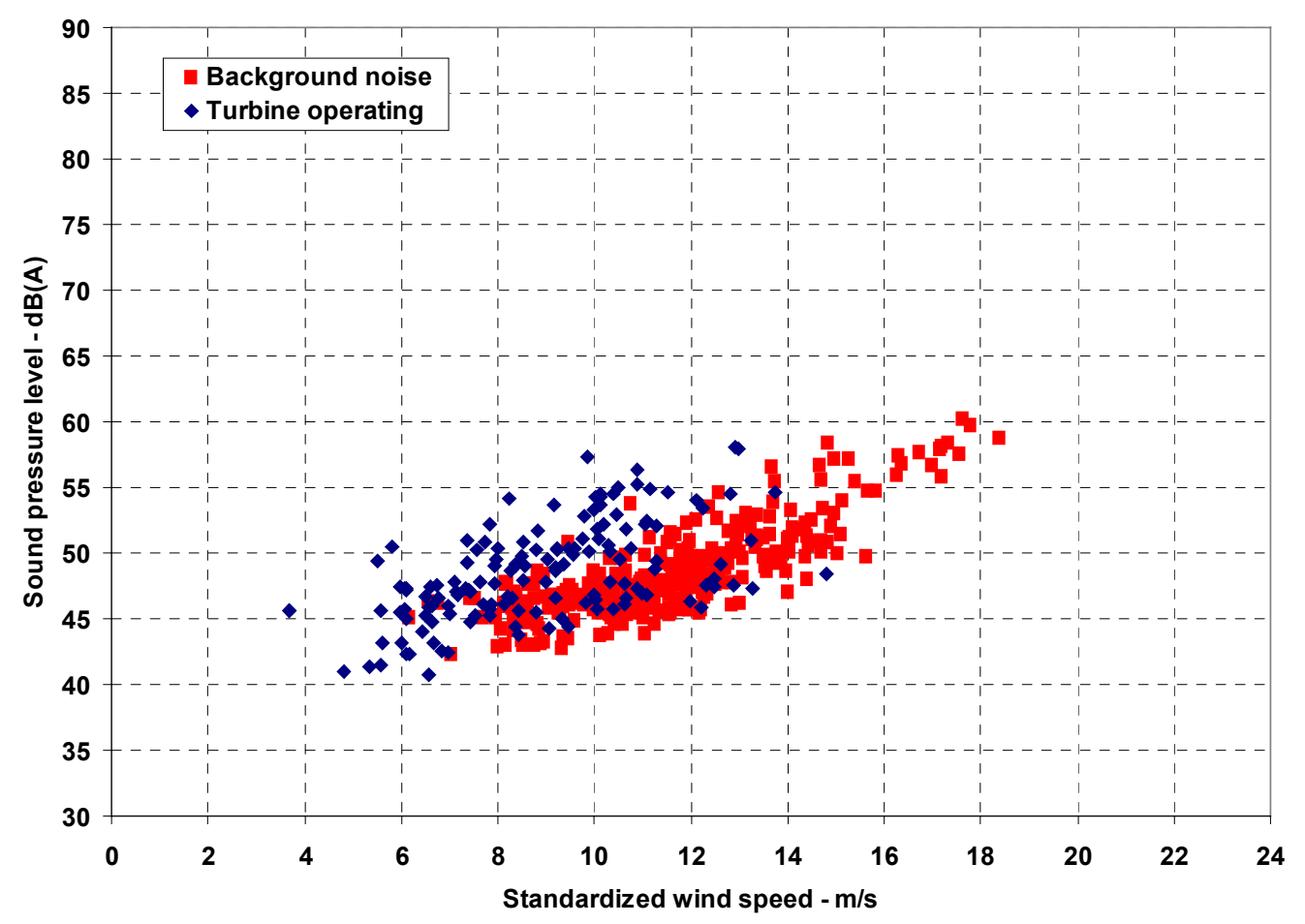

Figure 5. 10-second-average sound pressure level for Bergey XL.1

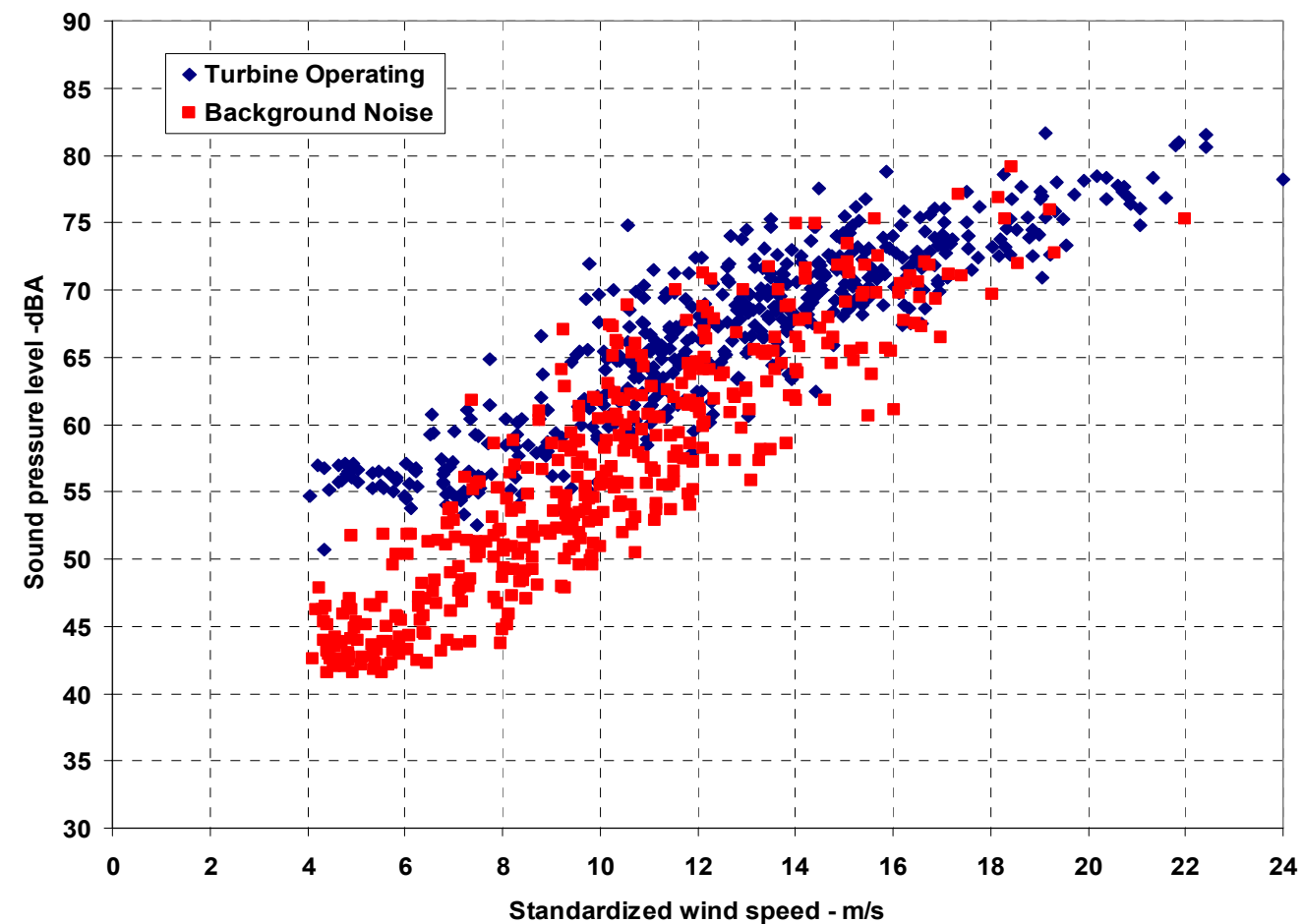

Figure 6. 10-second-average sound pressure level for Southwest Windpower Whisper H40 


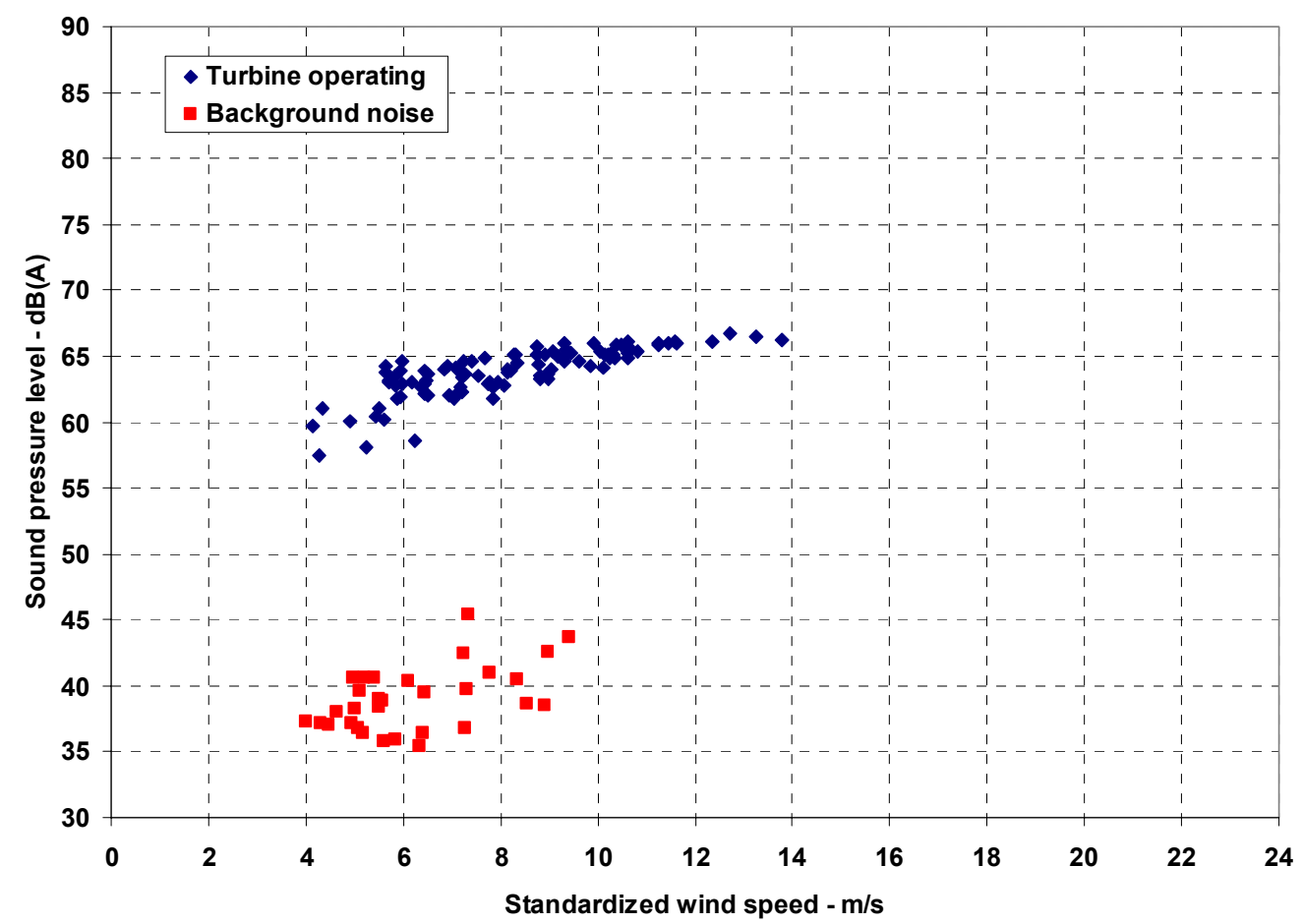

Figure 7. 1-minute-average sound pressure level for Atlantic Orient Corporation AOC 15/50

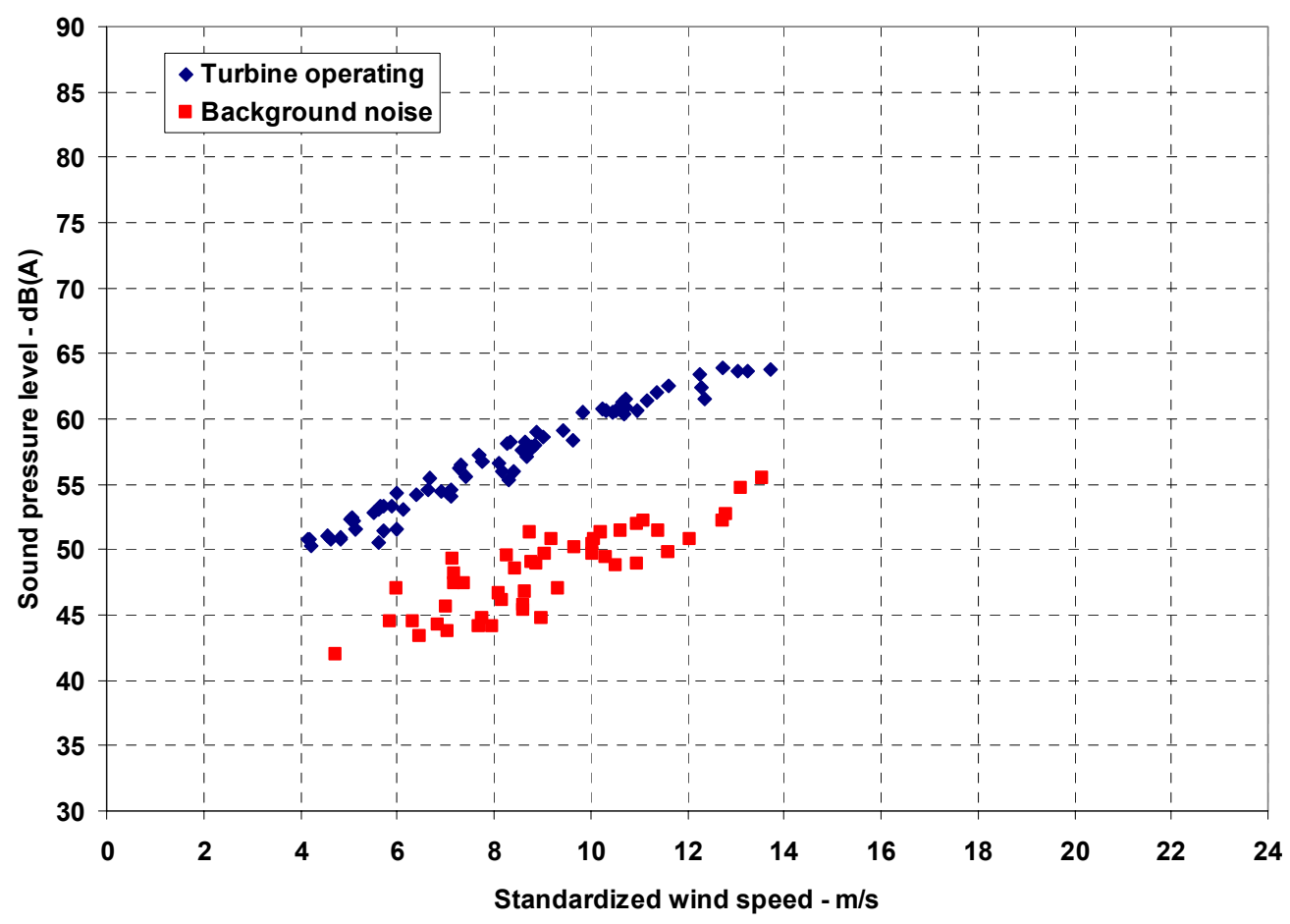

Figure 8. 1-minute-average sound pressure level for Northern Power Systems North Wind 100 


\begin{tabular}{|c|c|c|c|c|c|c|c|c|c|c|c|c|c|c|}
\hline & \multicolumn{14}{|c|}{ Wind Speed $(\mathrm{m} / \mathrm{s})$} \\
\hline & 3 & 4 & 5 & 6 & 7 & 8 & 9 & 10 & 11 & 12 & 13 & 14 & 15 & 16 \\
\hline AIR 403 & *** & ** & ** & ** & ** & 80.9 & 84.2 & 86.7 & 92.9 & 90.5 & 97.7 & 98.0 & -- & $\overline{--}$ \\
\hline AIR X & 73.1 & 76.6 & 78.8 & 77.7 & 77.5 & ** & 81.3 & 85.2 & 88.9 & 90.0 & 88.8 & 92.0 & 94.0 & 101.6 \\
\hline Whisper H40 & -- & 82.6 & 83.8 & 82.8 & 83.5 & 85.3 & 87.4 & 91.0 & 92.4 & $* *$ & 96.3 & ** & ** & ** \\
\hline$X L .1$ & -- & -- & -- & $* *$ & ** & ** & 75.8 & 78.7 & 78.0 & ** & 80.8 & -- & -- & -- \\
\hline Excel BW03 & -- & ** & 87.2 & 91.0 & 96.1 & 99.5 & 102.2 & 105.4 & 107.6 & 109.8 & 112.2 & -- & -- & -- \\
\hline Excel SH3052 & -- & -- & - & -- & 90.7 & 90.7 & 92.3 & 93.4 & 95.1 & 96.9 & 99.0 & 100.3 & 101.5 & -- \\
\hline$A O C$ 15/50 & -- & 96.9 & 96.9 & 100.1 & 100.8 & -- & 101.9 & -- & -- & -- & -- & -- & -- & -- \\
\hline North Wind 100 & -- & -- & -- & 89.6 & 91.9 & 93.9 & 95.1 & 97.0 & 98.1 & 99.6 & 100.8 & -- & -- & -- \\
\hline
\end{tabular}

-- Insufficient data are available.

** Separation between operating turbine and background noise is less than $3 \mathrm{~dB}$.

$b$ Numbers in italics have separation between operating turbine and background noise of between 3 and $6 \mathrm{~dB}$.

Table 1. Apparent sound power level for turbines with at least $3 \mathrm{~dB}(A)$ separation from background noise. Values were obtained by the bin analysis method described on page 3.

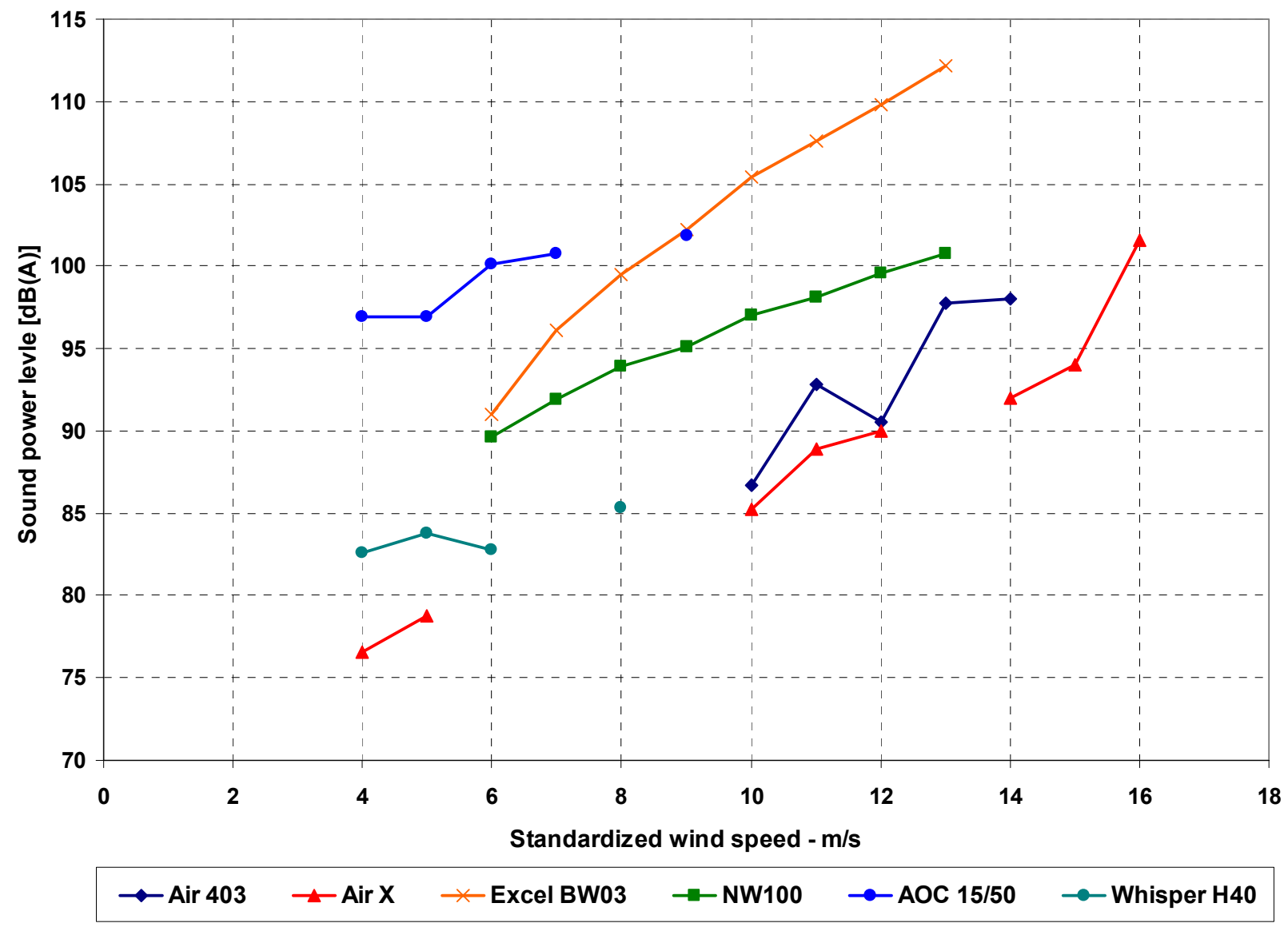

Figure 9. Apparent sound power level for turbines with at least $6 d B(A)$ separation from background noise. Values were taken from Table 1. 


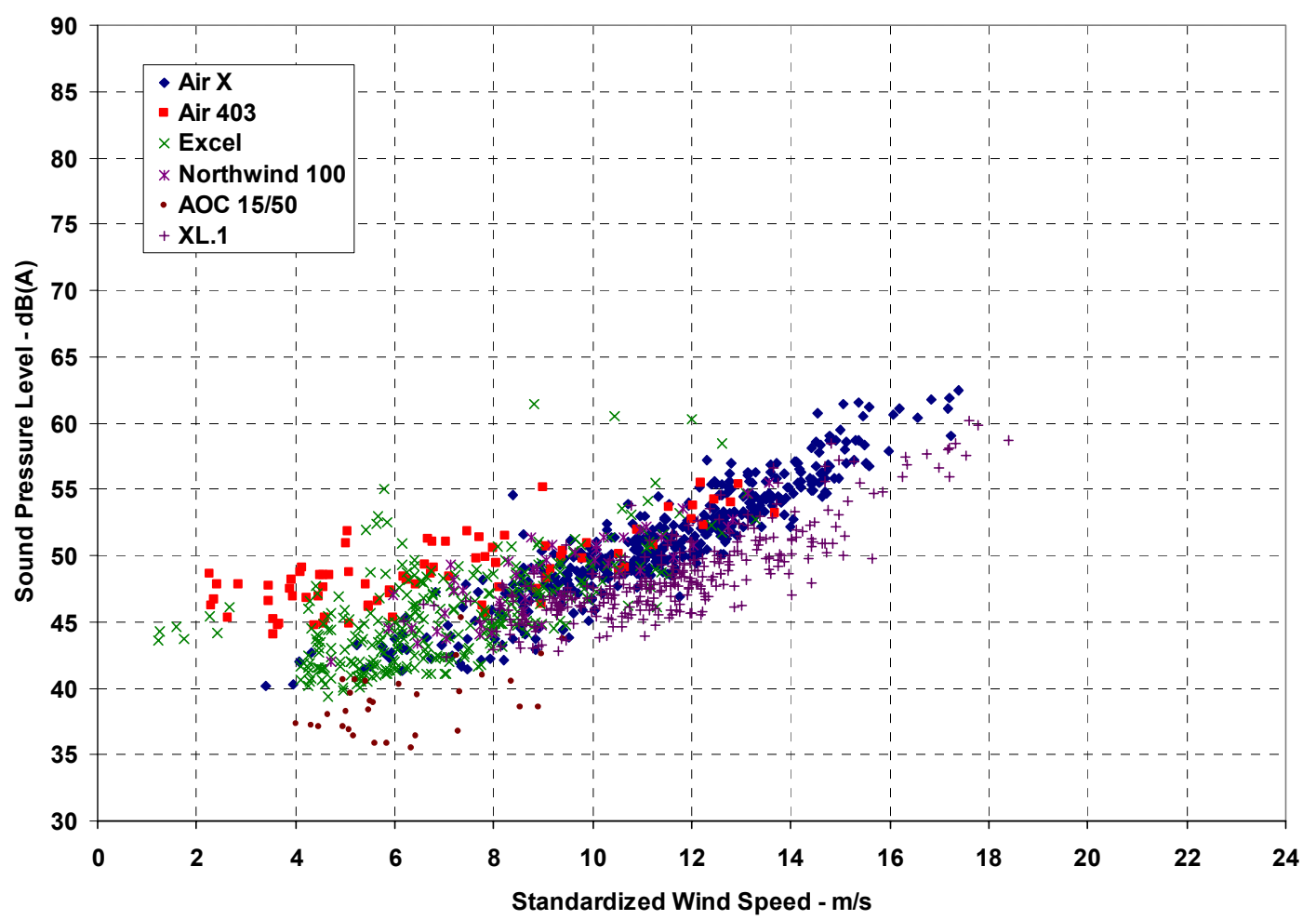

Figure 10. Background sound pressure level for several of the turbines tested. 


\section{REPORT DOCUMENTATION PAGE}

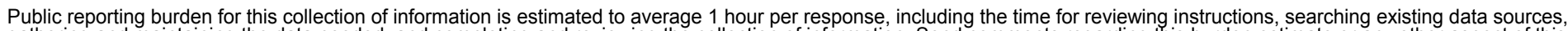

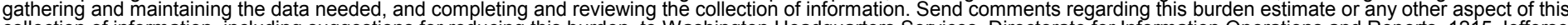
Headquarters Services, Directorate for Information Davis Highway, Suite 1204, Arlington, VA 22202-4302, and to the Office of Management and Budget, Paperwork Reduction Project (0704-0188), Washington, DC 20503.
1. AGENCY USE ONLY (Leave blank)
2. REPORT DATE
October 2003
3. REPORT TYPE AND DATES COVERED
Conference paper

4. TITLE AND SUBTITLE

Acoustic Tests of Small Wind Turbines: Preprint

6. AUTHOR(S)

P. Migliore, J. van Dam, A. Huskey

7. PERFORMING ORGANIZATION NAME(S) AND ADDRESS(ES)

National Renewable Energy Laboratory

1617 Cole Blvd.

Golden, CO 80401-3393

9. SPONSORING/MONITORING AGENCY NAME(S) AND ADDRESS(ES)

5. FUNDING NUMBERS

WER3-1830

8. PERFORMING ORGANIZATION REPORT NUMBER

NREL/CP-500-34662

10. SPONSORING/MONITORING AGENCY REPORT NUMBER

11. SUPPLEMENTARY NOTES

12a. DISTRIBUTION/AVAILABILITY STATEMENT

National Technical Information Service

12b. DISTRIBUTION CODE

U.S. Department of Commerce

5285 Port Royal Road

Springfield, VA 22161

13. ABSTRACT (Maximum 200 words)

Eight small wind turbines ranging from 400 watts to $100 \mathrm{~kW}$ in rated power were tested for acoustic emissions at the U.S. Department of Energy's National Renewable Energy Laboratory. Rigorous test procedures based on international standards were followed for measurements and data analyses. Results are presented in the form of sound pressure level versus wind speed, where the sound was recorded downwind of the turbine at a distance equal to the hub height plus half the rotor diameter. When there was sufficient separation between wind turbine noise and background noise, the apparent sound power level was calculated. In several cases, this was not possible. The implications of this problem are discussed briefly. Some of the configurations tested were specifically developed to reduce the noise level of their predecessors. Test data for these machines demonstrate marked progress toward quieter turbines.

small wind turbine acoustic tests; wind turbine noise

15. NUMBER OF PAGES

16. PRICE CODE

17. SECURITY CLASSIFICATION

OF REPORT

Unclassified

18. SECURITY CLASSIFICATION OF THIS PAGE Unclassified
19. SECURITY CLASSIFICATION OF ABSTRACT

Unclassified
20. LIMITATION OF ABSTRACT

UL 